\title{
Influence of Blasting Parameters and Density of Rocks on Blast Performance at Tschudi Mine, Tsumeb, Namibia
}

\author{
Martin Itoolwa Kulula, Maria Ndeapo Nashongo, Jide Muili Akande \\ Department of Mining and Metallurgical Engineering, University of Namibia, Windhoek, Namibia \\ Email: jakande@unam.na,mkulula@unam.na,riahamor@gmail.com
}

How to cite this paper: Kulula, M.I., Nashongo, M.N. and Akande, J.M. (2017) Influence of Blasting Parameters and Density of Rocks on Blast Performance at Tschudi Mine, Tsumeb, Namibia. Journal of Minerals and Materials Characterization and Engineering, 5, 339-352.

https://doi.org/10.4236/jmmce.2017.56028

Received: December 14, 2016

Accepted: September 28, 2017

Published: October 1, 2017

Copyright $\odot 2017$ by authors and Scientific Research Publishing Inc. This work is licensed under the Creative Commons Attribution International License (CC BY 4.0).

http://creativecommons.org/licenses/by/4.0/

(c) (i) Open Access

\begin{abstract}
A quantitative research was conducted at Tschudi mine, Tsumeb, Namibia with its main drive being to determine the influence that density and blast parameters has on the performance of a blast. The factors that are most vital to the fragmentation process are classified into three namely: explosive parameters, rock parameters and blast geometry. Rock fragmentation is dependent on two main factors, the rock properties which are uncontrollable and the blasting parameters that can be manipulated to give maximum efficiency. The selected variable quantities, density, charge length, volume of blast and mass of charge per hole were recorded after observation, determined via laboratory testing or calculated from their known equations. The main objective is to develop a model to predict blasting performance, and this will be achieved with the use of the Kuz-Ram model. The proposed equation related mean expected fragmentation size (calculated using the Kuz-Ram fragmentation model) to the actual fragmentation. Blasting parameters namely: burden, spacing, and charge quantity that are not included in this study were measured or calculated on site to facilitate the inputs of the Kuz-Ram model. A specialized software package SPLIT Desktop was used to estimate the actual mean fragmentation by analyzing scaled images from the post blast muck pile. The Microsoft Excel regression analysis correlated the two intact rock properties with the blasting efficiency. The expected mean fragmentation and the actual fragmentation were then used to determine the blast performance, defined as the percentage ratio of the actual mean to the expected mean. The blast performance showed a good relationship with density $\left(R^{2}=0.81971\right)$, with performance of the blast reducing with an increase in density. The performance also dropped with increase in charge length. The blast performance and mass of charge/explosives per hole relationship showed a correlation of $\left(R^{2}=0.56195\right)$, but the results were disregarded. Lastly the volume of the blast had a direct
\end{abstract}


relation to the blast performance $\left(R^{2}=0.80897\right)$ and it would be logical to state that, the two are directly proportional to each other.

\section{Keywords}

Fragmentation, Density, Kuz-Ram Model, Blasting Efficiency, Split Desktop, Regression Analysis

\section{Introduction}

Blasting is one of the most essential processes in mining. Blasting is the first step in the size reduction process in mining and it is followed by crushing and grinding unit operations. If carried out properly it eliminates further crushing and grinding of rocks. Therefore it affects almost all the proceeding processes. Blasting efficiency is not quite clearly understood because of different factors that influence it such as rock properties, explosive parameters and charge loading parameters. The blasting operations are designed to fracture the in-situ rock mass so as to prepare it for excavation and transportation operations. The run-of-mine (ROM) fragmentation is considered acceptable when it is fine and loose enough to ensure high efficiency in materials handling.

Tschudi is a low-cost open-pit mine extracting oxidized copper ore to be treated through heap-leach, solvent extraction and electro-winning. The mine is owned by Weatherly Mining Namibia, a subsidiary of UK-based miner Weatherly International and is located approximately $20 \mathrm{~km}$ west ( $26 \mathrm{~km}$ by road) of Tsumeb in northern Namibia see Figure 1.

\section{Experimental Procedures}

\subsection{Research Design}

This research was of quantitative nature done by conducting a series of experiments in the laboratory from samples collected in the field. The six rock samples were collected randomly from six blasts. There are three pits in operation and two samples were collected from each pit. The six samples were used to get the average density of the rock from that certain blast.

\subsection{Initial Observation of Blasting Parameters}

In order for the desired variable parameters to be observed and analyzed other parameters not part of the research are assumed to be constant constants. To counter this, observations were made on the entire blasting process, from the surveying and marking out of holes, drilling, charging, stemming, right through to the detonation of the blast. The survey and marking out of holes was very basic and simplistic giving rise to questionable accuracy, but however the methods used were consistent and done by the same people. Therefore any inherent errors were more systematic than random and therefore negligible. The blasting 


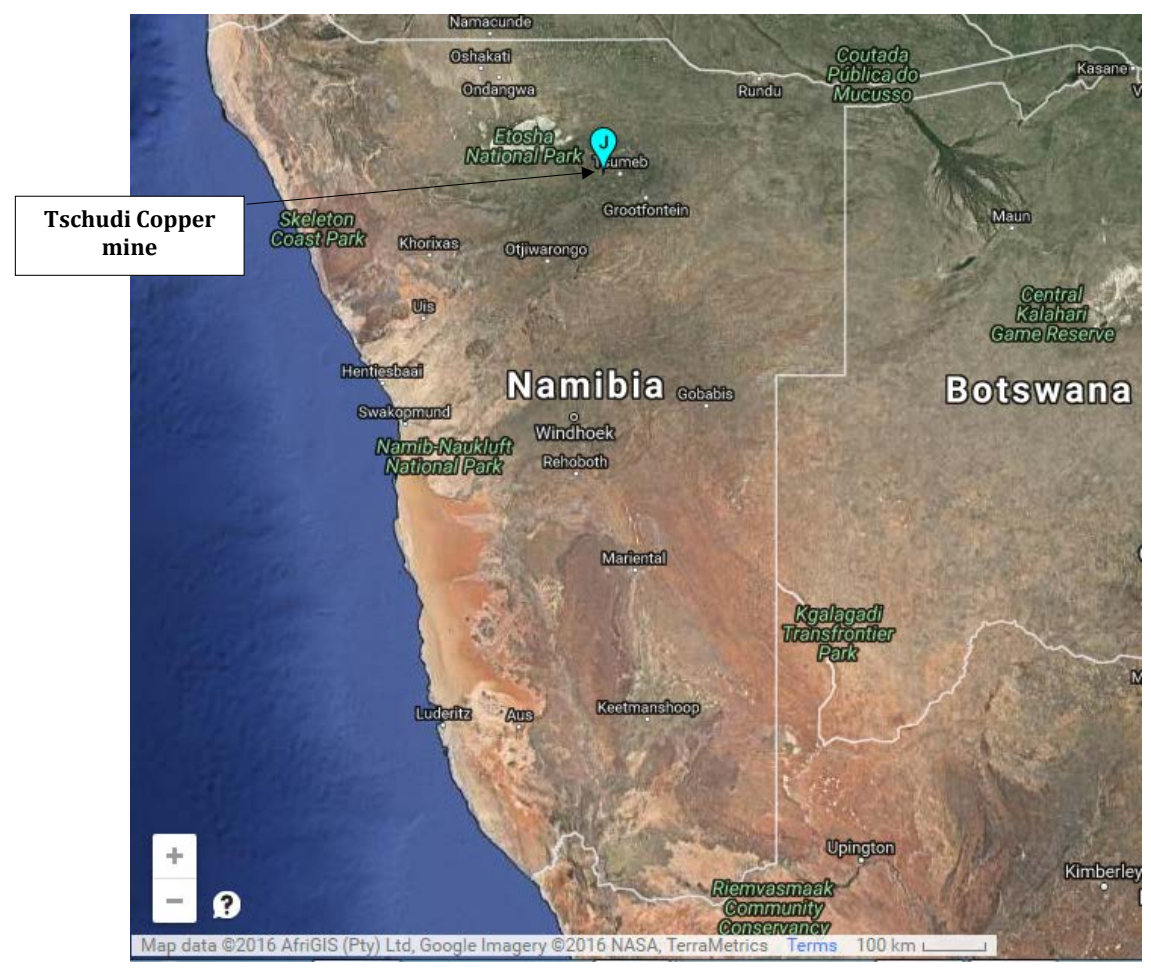

Figure 1. Location of Tschudi mine in Namibia [1].

pattern had different values based on the blasting block. The drilling team and rigs were also consistent, although it may be important to note that drill holes at the free faces were drilled at 75 and not 90 like the rest. Two of the parameters could not be assumed to be constant, namely the charge length and the volume of the blast. And therefore these parameters had to be included in the researched to show how their changes affected the blast fragmentation and ultimately the blast performance.

\subsection{Procedures}

\subsubsection{Collection of Samples}

A total of 6 samples were collected from the muck piles of each blast block, these were to be used for the determination of the rock mass property, density. The samples were picked randomly at the sites of the photographs taken for photographic analysis.

\subsubsection{Determination of Fragment Size Distribution}

The next phase of the research was the analyzing of the post blast block fragmentation distribution in order to find the $\times 50$ size that would then be compared to the Kuz-Ram $\times 50$ value for the determination of the blast performance. The most efficient way of analyzing the fragmentation distribution was through the use of the specialized software known as SPLIT. This software uses the input of scaled images/photographs of the muck pile to calculate the size distribution [2]. For the purpose of this research two tennis balls were used as scaling tools for the software to use. Each blast had five different images from the muck pile 
from different angles to cover as much of the pile a possible to fully represent the fragmentation. Excessive shadows when taking pictures were to be avoided as they complicated the boundary delineation process for the software. The software's inherent delineation algorithm was flawed and ultimately all rock boundaries had to be drawn in manually before the software could then calculate the size distribution curve. Examples of the software analyzing an image are shown in Figures 2-4 below.

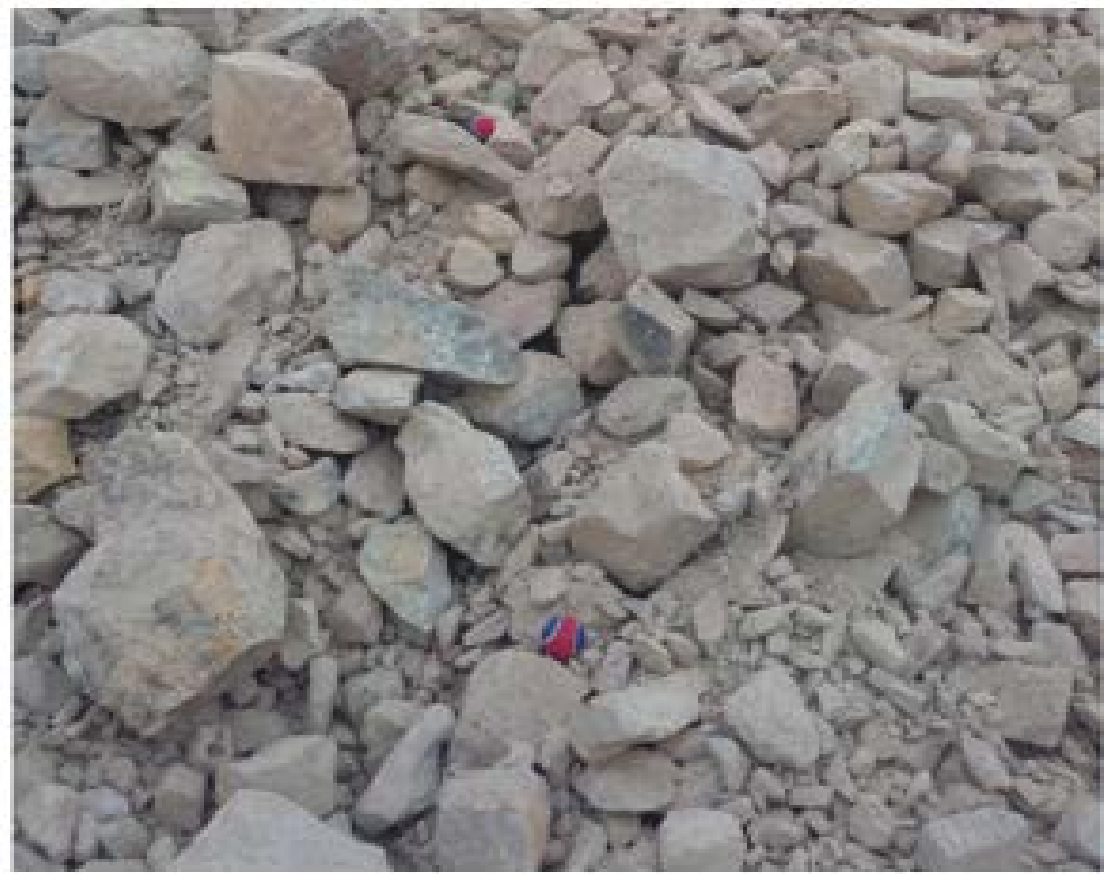

Figure 2. Sample image for SPLIT analysis.

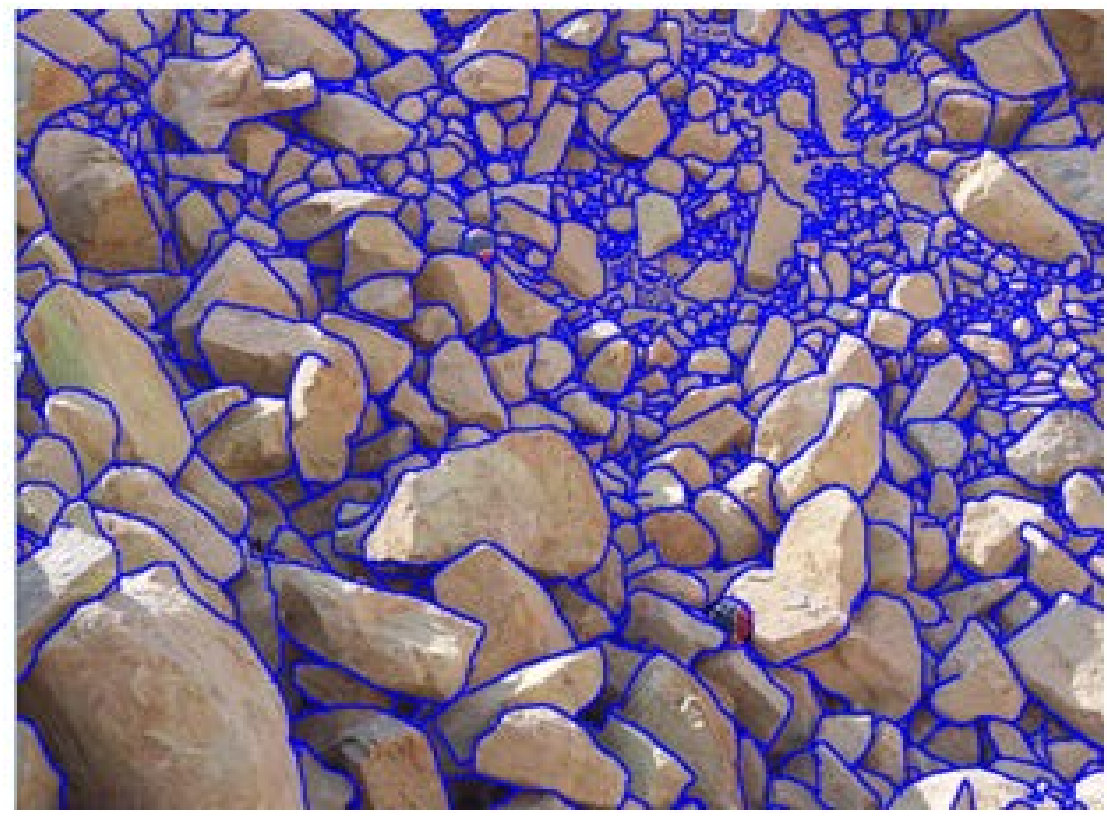

Figure 3. Analyzed image. 


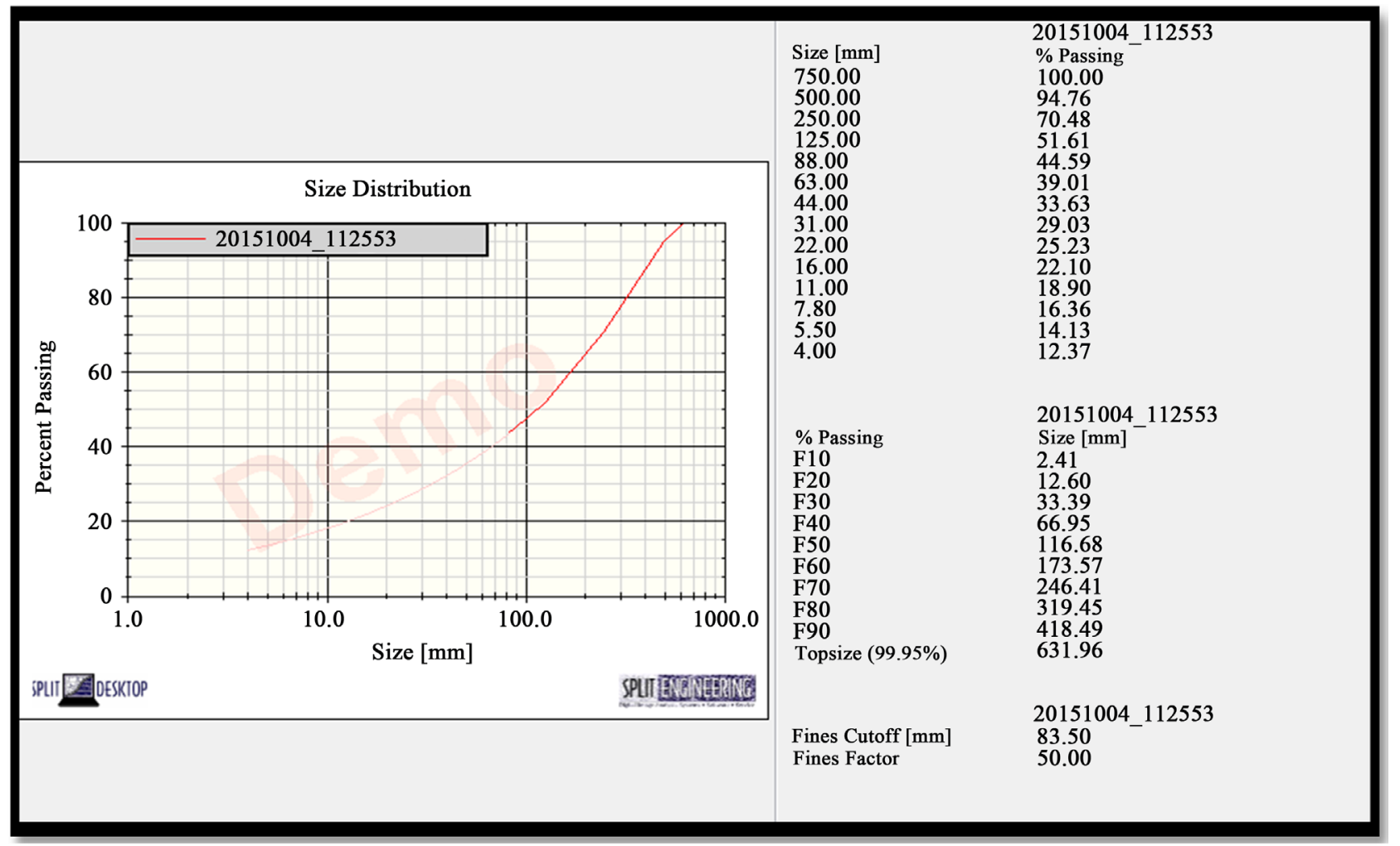

Figure 4. Particle size distribution curve (SPLIT output).

\subsubsection{Determination of Density of Rock}

Rock samples collected were handed to the geology department at Tschudi mine Tsumeb, Namibia to conduct tests to determine the density. The Archemede's principle of rock displacement was not used for this study as it was found to be giving inaccurate results after 3 trials were conducted.

\subsubsection{Determination of Volume of Blasted Material}

The volume of the blasted material was calculated directly using the formula

$$
V_{b}=B \times S \times L_{\text {avg }} \times n
$$

where: $V_{b}=$ Volume of blast, $B=$ Burden, $S=$ Spacing and $L_{\text {avg }}=$ average hole length

The average hole length will be calculated using the formula:

$$
L_{\text {avg }}=\frac{\sum \text { hole lengths }}{n}
$$

$n=$ number of holes

However for this research the average hole length of a blast was be calculated by the mapping software and given by the surveying team from Tschudi mine.

\subsubsection{Charge Length}

Charge length is defined as the actual length of the hole containing the explosive charge. The blasting parameters at the mine are such that a third of the hole is stemmed. This then means one point eight thirds of the hole is what is reserved 
for the explosive charge. The charge length (according to Tschudi Mine) was calculated as:

$$
\text { charge length }=\frac{1.8}{3} \times L_{a v g}
$$

\subsubsection{Mass of Charge/Hole}

After all the blast holes were charged, the mass of charge per hole was calculated using the formula:

$$
\text { Mass of charge per hole }=\frac{M_{\text {exp }}}{n}
$$

$M_{\text {exp }}=$ mass of explosive used for blast

\subsubsection{Determination of Blasting Parameters}

The blasting parameters which are the burden and spacing were measured using a tape measure.

\subsubsection{Determination of the Kuz-Ram Estimate Mean Block Fragmentation Size}

To determine the Kuz-Ram estimate mean block fragmentation size, the equation for the mean fragment size below, described by Mishra [3] was used.

$$
X=\frac{A \times Q^{0.167} \times\left(\frac{115}{E}\right)^{0.633}}{q^{0.8}}
$$

$Q=$ Specific charge $\mathrm{kg} / \mathrm{m}^{3}, Q=$ mass of explosive charge per hole, $\mathrm{kg}, E=$ relative weight strength of explosive (ANFO = 100), $A=$ a constant based on the rock factor (that depends on rock density, rock strength and jointing)

$$
A=0.06(\mathrm{RMD}+\mathrm{RDI}+\mathrm{HF})
$$

The rock characterization factor $A$ is calculated to correct the mean fragment size. It is made up of 3 factors which are the rock mass description (RMD), rock density influence (RDI) and the hardness factor (HF) [2].

\subsubsection{Determination of the Blasting Efficiency}

An equation created and defined by the author [4] was used to calculate the estimate blasting performance of each blast by using the percentage ratio of the expected mean block size fragmentation using the Kuz-Ram model and the actual observed mean block size from photographic analysis.

$$
\text { Blasting efficiency }=\frac{A F}{E F} \times 100
$$

where:

$A F=$ actual mean block fragmentation from photographic analysis. $E F=$ expected mean fragmentation from the Kuz-ram model.

\section{Results}

Experimental data collected from the field allowed for the density, mass charge 
per hole, charge length and volume to be determined. Before each blast operation could take place, blast parameters such as burden, spacing, number of drilled holes, average depth of blast hole, and the total mass of explosives used for charging the holes were recorded. All the above described parameters were then used as input the Kuz-Ram model. Snapshots taken of post-blast were used in Split-Desktop system to determine the actual mean fragment size.

The complete research project was done using data collected from the Tschudi mine, 3 blasts in Pit 4 and the other 2 in Pit 3. Each blast had a total of 5 images analyzed, the distribution with emphasis on the $\mathrm{x} 50$ mean block size for blast block P4-60-P2 and P3-18-P1 ( 2 of the 5 blast blocks) is shown in the Table 1 and Table 2.

\subsection{Image Analysis Results}

As Table 1 and Table 2.

Table 1. Blast P4-60-P2 image analysis.

\begin{tabular}{ccccccc}
\hline \%Passing & $\begin{array}{c}\text { Image 1 size } \\
(\mathrm{mm})\end{array}$ & $\begin{array}{c}\text { Image 2 size } \\
(\mathrm{mm})\end{array}$ & $\begin{array}{c}\text { Image 3 size } \\
(\mathrm{mm})\end{array}$ & $\begin{array}{c}\text { Image 4 size } \\
(\mathrm{mm})\end{array}$ & $\begin{array}{c}\text { Image 5 size } \\
(\mathrm{mm})\end{array}$ & $\begin{array}{c}\text { Average size } \\
(\mathrm{mm})\end{array}$ \\
\hline F10 & 119.86 & 46.7 & 5.67 & 82.67 & 23.45 & 47.53657 \\
F20 & 108.34 & 177.75 & 186.81 & 21.5 & 54.71 & 96.939 \\
F30 & 229.23 & 176.61 & 43.72 & 250.29 & 96.98 & 142.7721 \\
F40 & 238.47 & 278.3 & 70.31 & 90.28 & 304.15 & 187.5983 \\
F50 & 326.73 & 307.01 & 101.95 & 354.72 & 120.11 & 233.625 \\
F60 & 381.49 & 380.52 & 134.63 & 403.70 & 236.8 & 280.59 \\
F70 & 440.77 & 456.45 & 174.03 & 455.57 & 172.33 & 329.8 \\
F80 & 509.14 & 551.8 & 217.38 & 524.68 & 324.73 & 387.98 \\
F90 & 597.87 & 270.76 & 609.52 & 234.94 & 382.35 & 457.995 \\
Top size & 776.37 & 808.74 & 394.61 & 796.56 & 316.87 & 597.5633 \\
\hline
\end{tabular}

Table 2. Blast P3-18-P1 image analysis.

\begin{tabular}{ccccccc}
\hline \%Passing & $\begin{array}{c}\text { Image 1 size } \\
(\mathrm{mm})\end{array}$ & $\begin{array}{c}\text { Image 2 size } \\
(\mathrm{mm})\end{array}$ & $\begin{array}{c}\text { Image 3 size } \\
(\mathrm{mm})\end{array}$ & $\begin{array}{c}\text { Image 4 size } \\
(\mathrm{mm})\end{array}$ & $\begin{array}{c}\text { Image 5 size } \\
(\mathrm{mm})\end{array}$ & $\begin{array}{c}\text { Average size } \\
(\mathrm{mm})\end{array}$ \\
\hline F10 & 36.62 & 16.6 & 72.54 & 31.3 & 19.05 & 32.33167 \\
F20 & 92.12 & 34.84 & 67.75 & 48.09 & 53.31 & 83.83167 \\
F30 & 171.95 & 53.76 & 298.5 & 109.44 & 103.81 & 102.56 \\
F40 & 232.3 & 74.12 & 371.61 & 151.18 & 141.97 & 187.55 \\
F50 & 190.28 & 176.23 & 201.06 & 176.23 & 201.06 & 232.7317 \\
F60 & 357.31 & 112.45 & 507.57 & 228.77 & 211.03 & 278.0717 \\
F70 & 432.55 & 132.16 & 576.75 & 271.51 & 249.59 & 328.235 \\
F80 & 516.61 & 154.97 & 316.6 & 6290.99 & 367.8 & 384.3467 \\
F90 & 615.01 & 189.04 & 790.69 & 379.78 & 436.23 & 457.7 \\
Top size & 776.07 & 254.71 & 998.34 & 422.56 & 540.82 & 591.0067 \\
\hline
\end{tabular}




\subsection{Blast Parameters}

Some blast parameters were recorded for the purpose of providing data for the analysis of critical elements of formulas of the research. These parameters namely the number of blast holes, average hole length, burden, spacing and total mass of explosives were recorded and shown in the Table 3.

The following Tables 4-6 shows the results of the calculations of the three blasting parameters; namely the mass of charge per hole, volume of blasted ma-

Table 3. Observed blast parameters.

\begin{tabular}{cccccc}
\hline $\begin{array}{c}\text { Blast block } \\
\text { number }\end{array}$ & $\begin{array}{c}\text { Number of } \\
\text { blast holes }\end{array}$ & $\begin{array}{c}\text { Average hole } \\
\text { length }(\mathrm{m})\end{array}$ & $\begin{array}{c}\text { Burden } \\
(\mathrm{m})\end{array}$ & $\begin{array}{c}\text { Spacing } \\
(\mathrm{m})\end{array}$ & $\begin{array}{c}\text { Total mass of ex- } \\
\text { plosives }(\mathrm{kg})\end{array}$ \\
\hline P4-60-P2 & 486 & 12.5 & 5.0 & 5.0 & $56,608.00$ \\
P3-18-P1 & 123 & 6.5 & 4.7 & 4.7 & 3198.00 \\
P4-60-P4 & 554 & 12.8 & 5.5 & 5.5 & $61,303.00$ \\
P3B-87-P1 & 994 & 6.4 & 4.7 & 4.7 & $41,138.00$ \\
P4-48-P1 & 525 & 12.4 & 5.0 & 5.0 & $35,911.00$ \\
\hline
\end{tabular}

Table 4. Mass of charge/explosives per hole.

\begin{tabular}{cccc}
\hline $\begin{array}{c}\text { Blast block } \\
\text { number }\end{array}$ & $\begin{array}{c}\text { Number of } \\
\text { blast holes }\end{array}$ & $\begin{array}{c}\text { Mass of explosives } \\
\text { for the blast (kg) }\end{array}$ & $\begin{array}{c}\text { Mass of charge } \\
\text { per hole (kg) }\end{array}$ \\
\hline P4-60-P2 & 525 & $51,683.00$ & 98.44 \\
P4-48-P1 & 554 & $61,303.00$ & 110.66 \\
P4-60-P4 & 994 & $35,911.00$ & 36.18 \\
P3B-87-P1 & 123 & 3198.00 & 26.00 \\
P3-18-P1 & 486 & $56,608.00$ & 116.50 \\
\hline
\end{tabular}

Table 5. Volume of blast.

\begin{tabular}{cccccc}
\hline Blast number & Burden $(\mathrm{m})$ & Spacing $(\mathrm{m})$ & $\begin{array}{c}\text { Average hole } \\
\text { length }(\mathrm{m})\end{array}$ & $\begin{array}{c}\text { Number of } \\
\text { blast holes }\end{array}$ & $\begin{array}{c}\text { Volume of } \\
\text { blast }\left(\mathrm{m}^{3}\right)\end{array}$ \\
\hline P4-60-P2 & 5.0 & 5.0 & 12.5 & 486 & $151,875.00$ \\
P3-18-P1 & 4.7 & 4.7 & 6.5 & 123 & $17,948.13$ \\
P4-60-P4 & 5.5 & 5.5 & 12.8 & 554 & $215,508.80$ \\
P3B-87-P1 & 4.7 & 4.7 & 6.4 & 994 & $140,527.74$ \\
P4-48-P1 & 5.0 & 5.0 & 12.4 & 525 & $162,750.00$ \\
\hline
\end{tabular}

Table 6. Charge length.

\begin{tabular}{ccc}
\hline Blast number & Average hole length $(\mathrm{m})$ & Charge length $(\mathrm{m})$ \\
\hline P4-60-P2 & 12.40 & 7.44 \\
P4-48-P1 & 12.50 & 7.50 \\
P4-60-P4 & 6.50 & 3.90 \\
P3B-87-P1 & 6.40 & 3.84 \\
P3-18-P1 & 12.80 & 7.68
\end{tabular}


terial and the charge length. These were calculated according the Equations (3.1)-(3.4) stated in the Experimental procedure chapter.

The values of mass of charge per hole varied across all the five blasts but this was expected because, the average length of holes for each blast varied, while the diameters of all holes remained constant. Volume of the blast varied directly with the geometry of the area to be blasted and the average hole length.

The following Table 7 shows values for elastic modulus and compressive strengths which were obtained from the tests conducted by a laboratory on behalf of the Tschudi mine in management of Weatherly PLC, during a feasibility study made. These results are based on uniaxial compressive tests on cored samples.

\subsection{Rock Mass Properties}

\section{As Table 7.}

\subsection{Kuz-Ram Fragmentation Model Results}

The following tables are co-related; the first determines the rock factor (A). Densities in the table are actual values, calculated from samples collected from blast muck piles. The calculated rock factor was then used to calculate the values for the second table which gave the blast performance. The relative weight strength of HEF was found in a BME manufacturer. The Table 8 indicates how the rock factor (A) is determined. The Table 9 shows the blast performance.

Table 7. Elastic modulus and UCS Values pit 3 and 4.

\begin{tabular}{|c|c|c|c|c|}
\hline & $\begin{array}{l}\text { Elastic modulus, } \\
\text { Pit } 4(\mathrm{GPa})\end{array}$ & $\begin{array}{l}\text { Elastic modulus, } \\
\text { Pit } 3 \text { (Gpa) }\end{array}$ & $\begin{array}{l}\text { UCS Pit } 4 \\
(\mathrm{MPa})\end{array}$ & $\begin{array}{c}\text { UCS Pit } 3 \\
(\mathrm{MPa})\end{array}$ \\
\hline & 85.30 & 68.90 & 201.70 & 210.00 \\
\hline & 64.40 & 56.70 & 108.10 & 130.40 \\
\hline & 77.90 & 93.10 & 372.20 & 223.40 \\
\hline & 79.60 & 69.80 & 366.40 & 134.2 \\
\hline & 80.60 & - & 146.80 & - \\
\hline Average & 77.56 & 72.10 & 239.03 & 174.425 \\
\hline
\end{tabular}

Table 8. Determining rock factor (A).

\begin{tabular}{ccccccccc}
\hline Blast number & RMD & $\begin{array}{c}\text { Density } \\
\left(\mathrm{g} / \mathrm{cm}^{3}\right)\end{array}$ & $\begin{array}{c}\text { Density } \\
\left(\mathrm{kg} / \mathrm{m}^{3}\right)\end{array}$ & RDI & $\mathrm{Y}$ & UCS & HF & A \\
\hline P4-60-P2 & 50 & 2.72 & 2720 & 18.00 & 77.56 & 239.04 & 47.81 & 6.95 \\
P4-48-P1 & 50 & 2.70 & 2700 & 17.50 & 77.56 & 239.04 & 47.81 & 6.91 \\
P4-60-P4 & 50 & 2.72 & 2720 & 18.00 & 77.56 & 239.04 & 47.81 & 6.95 \\
P3B-87-P1 & 50 & 2.66 & 2660 & 16.50 & 72.10 & 174.43 & 34.89 & 6.08 \\
P3-18-P1 & 50 & 2.80 & 2800 & 20.00 & 72.10 & 174.43 & 34.89 & 6.29 \\
\hline
\end{tabular}


Table 9. Determining blast performance.

\begin{tabular}{ccccccccccc}
\hline $\begin{array}{c}\text { Blast } \\
\text { number }\end{array}$ & $\begin{array}{c}\text { Rock } \\
\text { factor } \\
(\mathrm{A})\end{array}$ & $\begin{array}{c}\text { Volume } \\
\text { of blast }\left(\mathrm{m}^{3}\right)\end{array}$ & $\begin{array}{c}\text { Total mass of } \\
\text { explosive }(\mathrm{kg})\end{array}$ & $\begin{array}{c}\text { Specific } \\
\text { charge } \\
\left(\mathrm{kg} / \mathrm{m}^{3}\right)\end{array}$ & $\begin{array}{c}\text { Mass of } \\
\text { per hole } \\
(\mathrm{kg})\end{array}$ & $\begin{array}{c}\text { Relative weight } \\
\text { strength of ex- } \\
\text { plosive } \\
(\text { Hefloo })\end{array}$ & $\begin{array}{c}\text { Mean } \\
\text { block size } \\
\text { Kuzram } \\
(\mathrm{cm})\end{array}$ & $\begin{array}{c}\text { Mean } \\
\text { block size } \\
\text { Kuzram } \\
(\mathrm{mm})\end{array}$ & $\begin{array}{c}\text { Mean } \\
\text { Block } \\
\text { Size image } \\
(\mathrm{mm})\end{array}$ & $\begin{array}{c}\text { Berfast } \\
\text { Permance } \\
(\%)\end{array}$ \\
\hline P4-60-P2 & 6.95 & $151,875.00$ & $56,608.00$ & 0.32 & 116.50 & 87.00 & 77.19 & 771.95 & 223.63 & 28.97 \\
P4-48-P1 & 6.29 & $162,750.00$ & $51,683.00$ & 0.27 & 98.44 & 87.00 & 75.87 & 758.73 & 232.75 & 30.67 \\
P4-60-P4 & 6.95 & $215,508.00$ & $61,303.00$ & 0.37 & 110.66 & 87.00 & 99.84 & 998.39 & 211.80 & 21.21 \\
P3B-87-P1 & 6.08 & $140,527.74$ & $35,911.00$ & 0.37 & 36.13 & 87.00 & 86.67 & 866.75 & 167.98 & 19.38 \\
P3-18-P1 & 6.91 & $17,948.13$ & 3198.00 & 0.27 & 26.00 & 87.00 & 67.12 & 671.21 & 389.19 & 57.98 \\
\hline
\end{tabular}

The ultimate results of the blast performance were calculated, after all the other calculations were completed. The equation takes one of two different forms depending on the actual mean size and the expected mean size.

This has the possible application of fragmentation performance optimization were several blasts are to be analyzed.

This gives rise to a new term called the comparative blast performance given by the following equations under the given set of conditions.

$A F=$ Actual mean size

$E F=$ Expected mean size

Scenario 1: If $E F>A F$

$$
\text { Blasting efficiency }=1-\frac{A F}{E F} \times 100
$$

Scenario 2: if $E F<A F$

$$
\text { Blasting efficiency }=\frac{A F}{E F} \times 100
$$

With the modifications of the formula by the author [3], the comparative blast performance can then be used to compare the performance of different blasts. The results of this research fall under scenario 1 , therefore the new Table 10 shows comparative blast performance.

\section{Analysis and Discussion}

\subsection{The Blast Performance}

The comparative blast performance was then analyzed using regression to determine its relation to rock density; the blasting parameters charge length, mass of explosive per hole and the volume of the blast. The respective linear regression plots are shown Figures 5-8.

The $R^{2}$ values and equations for the above analysed parameters are shown in the table below. The full regression analysis data is attached to the appendix D. The regression analysis results for various parameters are sumarised in Table 11.

\subsection{Mean Fragment Size Distribution}

The curve for the predicted and actual fragment size distributions for the blasts is shown in Figure 9. 


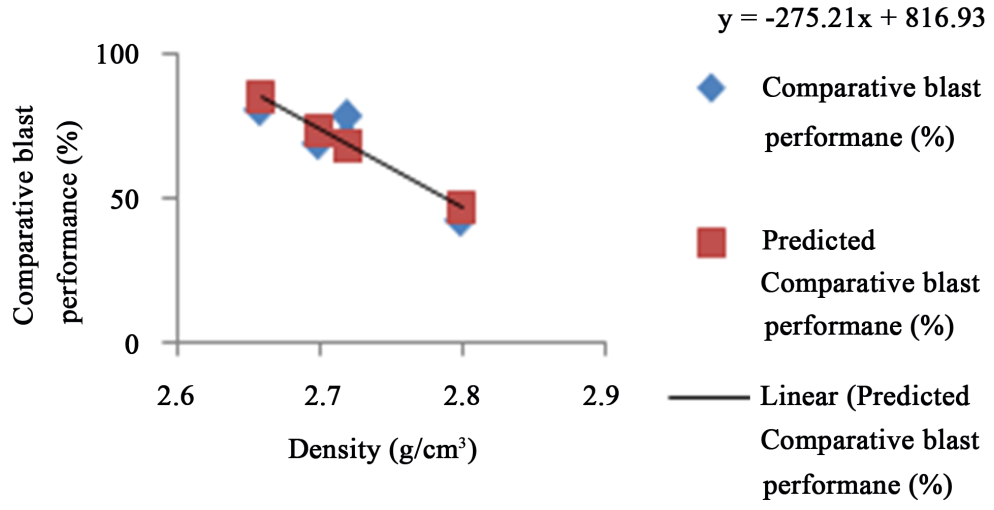

Figure 5. Comparative blast performance against density.

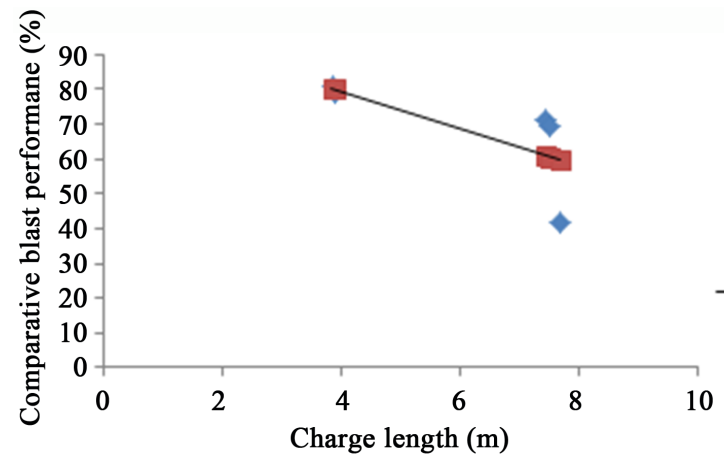

$y=-5.3925 x+101.1$

- Comparative blast performane (\%)

- Predicted Comparative blast performane (\%)

- Linear (Predicted Comparative blast performane (\%)

Figure 6. Comparative blast performance against charge length.

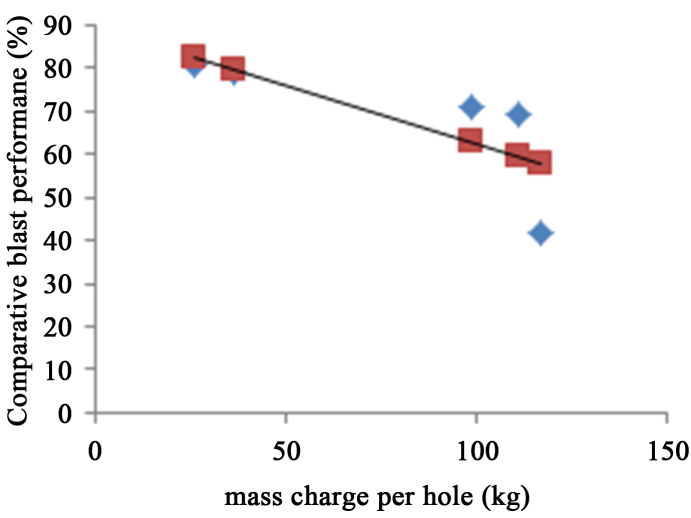

$y=-0.2698 x+89.283$

- Comparative blast performane (\%)

Predicted Comparative blast performane (\%)

Linear (Predicted Comparative blast performane (\%)

Figure 7. Comparative blast performance against mass charge per hole.

Table 10. Comparative blasting performance.

\begin{tabular}{ccccccc}
\hline $\begin{array}{c}\text { Blast block } \\
\text { number }\end{array}$ & $\begin{array}{c}\text { Blast perfor- } \\
\text { mance (\%) }\end{array}$ & $\begin{array}{c}\text { Comparative } \\
\text { blast } \\
\text { performance }(\%)\end{array}$ & $\begin{array}{c}\text { Density } \\
\left(\mathrm{g} / \mathrm{cm}^{3}\right)\end{array}$ & $\begin{array}{c}\text { Charge } \\
\text { length }(\mathrm{m})\end{array}$ & $\begin{array}{c}\text { Mass of } \\
\text { charge per } \\
\text { hole }(\mathrm{kg})\end{array}$ & $\begin{array}{c}\text { Volume of } \\
\text { blast }\left(\mathrm{m}^{3}\right)\end{array}$ \\
\hline P4-60-P2 & 28.96900687 & 71.03099313 & 2.72 & 7.44 & 98.44 & $151,875.00$ \\
P4-48-P1 & 30.67403157 & 69.32596843 & 2.70 & 7.50 & 110.66 & $162,750.00$ \\
P4-60-P4 & 21.2138829 & 78.7861171 & 2.72 & 3.90 & 36.18 & $215,508.80$ \\
P3B-87-P1 & 19.38091667 & 80.61908333 & 2.66 & 3.84 & 26.00 & $140,527.74$ \\
P3-18-P1 & 57.98290015 & 42.01709985 & 2.80 & 7.68 & 116.50 & $17,948.13$ \\
\hline
\end{tabular}




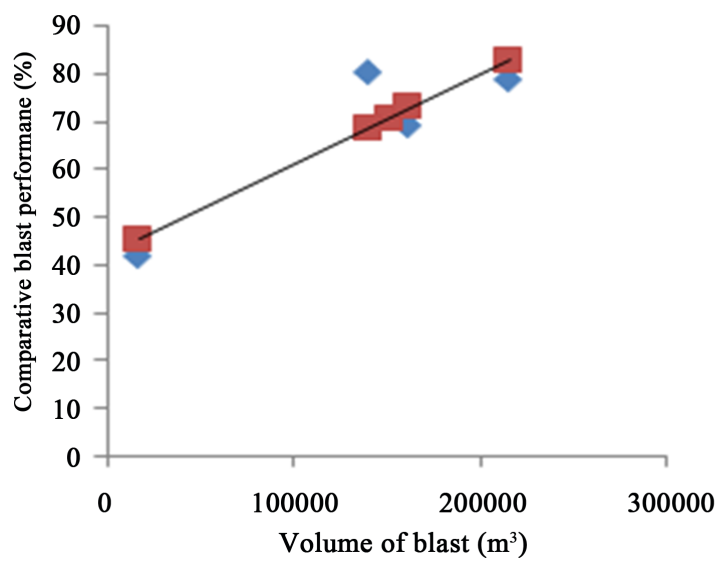

$y=0.0002 x+42.005$

Comparative blast performane (\%)

Predicted Comparative blast performane (\%)

Figure 8. Comparative blast performance against volume of blast.

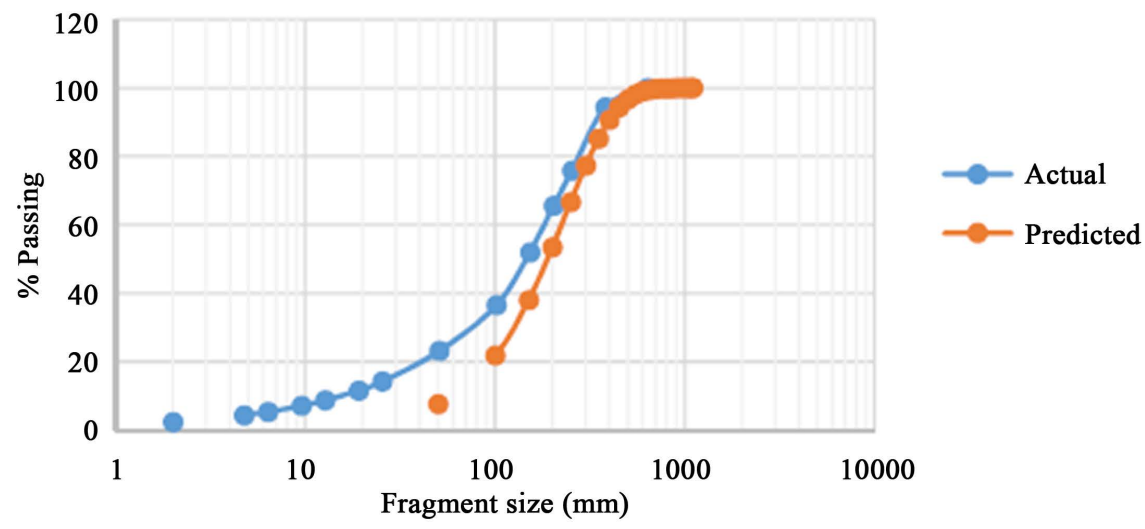

Figure 9. Actual vs. predicted fragment size distribution.

Table 11. Regression analysis results.

\begin{tabular}{cccc}
\hline Variable/parameters & $R^{2}$ & Equation & $P$-value \\
\hline Density & 0.82 & $\mathrm{y}=-275.21+816.93$ & 0.0344 \\
Charge length & 0.50 & $\mathrm{y}=-5.3925 \mathrm{x}+101.1$ & 0.1881 \\
Mass of explosive per hole & 0.56 & $\mathrm{y}=-0.2698 \mathrm{x}+89.283$ & 0.1446 \\
Volume of blast & 0.81 & $\mathrm{y}=0.0002 \mathrm{x}+42.005$ & 0.0377 \\
\hline
\end{tabular}

\subsection{Discussion}

Looking at the graphs and tables one can notice that as expected the comparative blast performance had a high correlation with the rock density, and as the graph shows the performance of the blast decreases fairly rapidly with an increase in density. Increase in density comes with higher strength and hardness and hence an increase in the fragmentation difficulty.

The graph of blast performance against charge length follows the same trend as the density graph, meaning that the blast performance reduces with an increase of charge length. As the length of the hole increases, so do the confinement forces making the rock harder to break. The deeper holes may also pene- 
trate through newer and un-weathered rock that has higher strength as well. The correlation however is lower, maybe due to the effects of other variables. The correlation may also be a little lower due to the varying confinement along the charge length, with many geological irregularities for each blast.

The relationship between performance and mass of charge per hole didn't follow the hypothesis and it showed that the performance would reduce with the increase in amount of charge. This does not go with the common knowledge that more charges means more energy and more energy means better blast performance. The only viable explanation for the strange graph is that the large differences in the average length of holes per blast means higher mass of charge readings are based on geometries of the blast holes and are meaningless. Therefore the mass of charge per hole would only be truly representative if all blasts had similar hole depths. As a hole may have more charge simply because it is longer, but increased confining stresses may still overcome the explosive resulting in blasting performance that is less than that of a shorter hole with a lesser amount of charge, but also with less confining forces.

The volume of blast seems to have a direct proportion correlation to the blast performance. The graph of comparative blast performance against volume of the blast also supports this with the line of fit which indicates a linear relationship, meaning when the volume of blast increases, the blast performance also increase. This is probably because fragmentation is really just about the parameters that surround a blast hole, this is then just duplicated to form a blasting pattern, the number of holes, and effectively the volume of the blast have effects to the blast performance. The larger the blasting block, then the evenly the mass of explosives is said to be distributed that a smaller portion.

Prediction of fragment size distribution using the Kuz-Ram model is a sensible way of fragmentation analysis. It is preferable to use than conventional sieving methods, which are more accurate but time consuming. Also, sieving methods become impractical to use for large muck pile fragmentation analysis. The major shortcoming of the Kuz-Ram fragmentation model is its inability to reproduce the fines part of the fragmentation model. In the MS Excel model used, the fines could only be estimated to a minimum of $50 \mathrm{~mm}$ in diameter. This means, the finer the actual fragmentation distribution, the larger the deviation between the predicted and the actual. When there are coarser materials than fines in the muck pile, the prediction of the Kuz-Ram model becomes much more accurate, and the gap between the actual and predicted curves becomes shallower.

\section{Conclusions and Recommendations}

\subsection{Conclusions}

Blast operations should encompass the generation of fragment size distribution which is suitable for downstream operations (crushing, grinding, etc.). This study centered on the analysis of the relationship among blast efficiency and 
density, charge length, mass of explosive/charge per hole and volume of blast. The main conclusions to this study are:

1) The Kuz-Ram model overestimated almost all of the fragment size distributions analyzed. However, this was expected since the model underestimates the fines part of the distribution curves;

2) The reliability of any fragmentation model to evaluate blast performance by analysis of blast parameters used prior to blasting depends on the accuracy of rock mass characterization and the ability to model and measure the amount of fines generated in blasting;

3) A regression model to predict blast performance in relation to variables was created;

4) Density was found to have an inverse relationship with blast performance, the higher the density, the lower the blast performance;

5) The blast performance vs. charge length relationship was found to be in error because of the variable nature of the hole length with each blast. An experiment setup with constant hole length is constant and would be more suitable to measure the effects of this parameter;

6) The volume of the blast was found to be directly proportional to the blast performance, such that when the volume of blast increases the blast performance increases too.

\subsection{Recommendations}

Although blast performance is overall efficient, the blast performance is of a concern. Boulders are almost always formed post-blast, which necessitates the need for secondary breakage either by blasting or mechanical means. Not only is this an expense to the plant, but poor fragmentation can result in stoppage of production or have an adverse effect of the primary crusher' performance

\section{References}

[1] Google (2016) Google Maps. https://www.google.com/maps/

[2] Cunningham, C.V. (2005) The Kuz-Ram Fragmentation Model-20 Years on. European Federation of Explosive Engineers, Brighton.

[3] Mishra, A. (2009) Design of Surface Blasts-A Computational Approach. National Institute of Technology, Rourkela.

[4] Adebayo, B. and Umeh, E.C. (2007) Influence of Some Rock Properties on Blasting Perfomance-A Case Study. Journal of Engineering and Applied Sciences, 2, 41-44. 